\title{
Correspondence
}

\section{Certificates and divorce}

SIR

I seek your assistance in preventing the misuse of certificates and reports issued by doctors in respect of or relating to persons engaged in matrimonial litigation. Much weight is given by the courts to these documents. In two particular areas injustice has occurred as a result of opinions being expressed without adequate justification.

I) The right of access to children by one divorced parent when the other has custody: the custodial parent may resent any relationship which the child may have with the other parent and seek to have it terminated. When stress symptoms occur in the child these are often ascribed to the 'bad influence' of the other parent, resulting in the issue of reports recommending withdrawal of access facilities on the grounds that the child is invariably 'upset' after contact with the other parent. Such opinions are often based on information derived from the custodial parent alone, and do not take into account the stressful effects of the broken marriage in general on the child. Children suffer greatly from divided loyalties to the parents and even greater stress is suffered when the child listens to the vilification of one parent by the other.

2) Maintenance: it has been common for some years for the courts to award maintenance - almost invariably to an exwife who has not re-married, from her former husband - in the sum of one third of their gross joint income. Some women, no longer prevented from working by the needs of their young children, see in current matrimonial law a way of acting out their hostility and of imposing a permanent and increasing burden on their former spouses, some of whom will have re-married and may have children by their second wives. In many cases (but not all) the courts appear to take the view that an ex-wife should work when her children no longer need her at home unless there is medical evidence that she is unfit to do so. Doctors who issue certificates of such unfitness to divorcees are asked to bear in mind that if their opinions are accepted by the courts, the most probable result will be the imposition of a substantial added burden on the former husband ad infinitum, irrespective of any apportionment of responsibility for the breakdown of the marriage. Certificates have been issued on what has subsequently turned out to be the flimsiest of grounds, 'backache', 'chronic anxiety state' and 'depression' being the most popular diagnoses. The effect upon the subsequent health of the former husband (and indeed on the other members of his new family) is likely to be of greater severity.

Increasingly doctors' opinions are being challenged in the courts. It is not difficult to understand the sympathy that a doctor may have for his patient and the pressures that can be brought to bear are appreciable. None the less it would seem to be appropriate and prudent by any standard to consider carefully the facts of the matter when confronted with requests for certificates or reports in these circumstances.

YVONNE MOFFATT Chairman Campaign for $\mathcal{F}$ ustice in Divorce

\section{Teaching of medical ethics}

SIR

I should like to respond to your thoughtful and well balanced editorial in the December 1981 issue dealing with the question of whether medical ethics should be taught within the medical school curriculum. One of us is a UK graduate of the ' $50 s$. We learned by precept and undoubtedly the role model of an ethical physician's activities were conveyed in this way. However, many issues were never formally considered and the choices in medical decisionmaking were not as intricate as today.

McGill has had formal undergraduate instruction in medical ethics for some time and this is supplemented by more informal small seminar groups. An attempt is being made to extend these into the hospital (as distinct from medical school) environment to include the care-giving teams of physicians, nurses etc. Our impression is that these efforts are worthwhile and appreciated by both doctors-to-be and those in graduate training. While concrete answers cannot be provided for all or even perhaps the majority of the complex problems facing physicians today, seminar-type instruction does provide a framework for considering the possible choices and guidelines to the most acceptable patient care in the 1980 s.

JOSEPH LELLA

Department of Humanities and Social Studies in Medicine McGill University MICHAEL KAYE Faculty of Religious Studies $M c$ Gill University and Division of Nephrology Montreal General Hospital 